\section{Cancer risk indicated}

\section{Paris}

ACCORDING to the preliminary results of an inquiry directed by Professor Jean Bernard, personnel at the Pasteur Institute in Paris could be more susceptible to rare forms of cancer than the French population as a whole. Although the 12 -member committee of inquiry says that further investigation is necessary, the results of the inquiry will strengthen concern about the seven Pasteur researchers who developed rare forms of cancer within a few years of each other. Two of them have since died (see Nature 338, 607; 1989).

The inquiry was set up in 1987 with the aim of tracking down as many as possible of the technical and research staff who had worked at the Pasteur Institute during the same period (1971 to the end of 1986) as the sick researchers. These researchers had worked in laboratories on the same floor and some of them had handled recombinant DNA products. Epidemiologists from Unit 170 of INSERM (the National Medical and Health Research Institutes) finally traced 3,765 individuals fitting the criteria.

Only mortality statistics have been analysed so far in the study. Out of the sample, 143 deaths were recorded, compared with 246 expected for the same age range in the French population as a whole. This lower death rate, says Annie Sasco, one of the epidemiologists from the Lyons laboratory which carried out the inquiry, is probably linked to the sample's higherthan average socioeconomic status. Of these 143 deaths, 51 were from cancers and 41 from cardiovascular disease. Both of these proportions are somewhat less than would be expected for the population as a whole.

Deaths from commoner forms of cancer were less frequent than expected, but those from cancers affecting the bone, the pancreas and the brain were higher. Two deaths from bone cancer were found, compared with an expected number of 0.58 , while six of the sample died from cancer of the pancreas, compared with an expected 2.67 .

The sample data do not permit conclusions about risks at the Pasteur, said Sylvaine Cordier, an epidemiologist who was also part of the inquiry committee. The study needs to be followed up by research into morbidity, she said.

Other people may have developed cancer and been cured, or may be developing illnesses that have not yet proved fatal. Further studies taking into account environmental factors, such as the kinds of products handled or exposure to radiation, are now necessary.

Peter Coles

\title{
Soviet influx opens new era
}

\section{Jerusalem}

SCIENCE and technology are certain to be profoundly affected by the massive influx of Soviet Jews which is already beginning to change the face of Israel. As many as one million émigrés may arrive before the end of the decade, increasing the Israeli population by a quarter and tripling the size of the scientific community.

Baruch Eyal, head of human resources and international research institutes at the Science and Technology Ministry, says that the official forecast figures are "quite astounding; for every 100,000 immigrants, 42,000 are professionals, including a particularly high percentage of engineers and about 2,000 scientists, 1,500 of whom are in natural and exact sciences, with the remainder in social sciences. This is five times higher than the concentration of scientists in Israel and the West generally." In January alone, 6,170 Soviet citizens landed in Israel, and the proportion of scientists among them reflects Eyal's forecast figures.

The Science and Technology Ministry has been formulating plans to absorb these professionals and welcomes proposals from scientists still waiting to leave the Soviet Union. Ministry officials claim to be making special efforts to ensure that the émigrés stay in Israel rather than move on to the higher salaries in the United States and Canada. But scientists in industry accuse the government of "laziness" and argue that it is still not doing enough to prepare for the great influx.

Eyal responds by saying that "so far, the ministry has earmarked an initial \$3 million for the employment of Soviet scientists, with a focus on the fields of biotechnology, materials, computer science and artificial intelligence, electrooptics and lasers, neurobiology, superconductivity, and environmental sciences". A Soviet scientist who finds work, whether in a university or in industry, will be able to keep that government salary rather than strain the budget of the institution in question.

The Israeli Academy of Sciences has also announced the allocation of $\$ 6.3$ million, through a private fund, for 15 senior Soviet scientists. The money will be used to establish chairs in their fields of expertise and for housing loans and fiveyear research grants.

A second ministry plan is to strengthen existing infrastructure. Israel's seven universities are short of funds and do not have the means to increase their staff but "no one wants to waste the resources", says Eyal, "especially in the case of 'exceptional' scientists and those with specific knowhow, such as biotechnologists." There are plans to set up a biotechnology institute within the Institute of Applied Sciences at
Beersheba, and possibly an institute for opto-electronics.

Software engineers - which in the Soviet case means mathematicians - will be much in demand, given the potential for creating exportable items without massive investment in plant. Efforts will also be made to encourage scientists to move into school teaching.

To facilitate implementation of the ministry's plans, a new computer network will link the ministry with universities and industry and representatives in Moscow.

The influx of immigrants is likely to increase competiton for jobs. Eyal stresses that it is "important that a gap does not develop between immigrants and demobilized soldiers, new graduates and other Israelis competing for the same jobs". But Shmuel Adler, who heads the Absorption Ministry's Centre for Absorption in Science, warns that "Israelis have to learn that in the question of manpower, the best one will win." Since the centre was set up in 1974, Adler says that it has helped 4,500 scientists start work, half of them from the Soviet Union.

One enterprising example of 'scientific absorption' was initiated by Herman Branover, professor of mechanical engineering at Ben-Gurion University of the Negev, in the southern city of Beersheba. His Jerusalem-based Shamir Advanced Technologies Engineering Centre (SATEC) employs about 60 people, of whom 35 are new immigrants. Its principal products are digital electric power meters, low-technology heating elements and hydro-metallurgic techniques for extracting precious metals.

SATEC's scientists are all of Soviet origin - including Branover who arrived in 1972 - while the company's marketing and finance is handled by American- and British-born Israelis who immigrated with skills that native Israelis could not provide.

Branover says that not enough people in government or industry appreciate the scale of the new migration. "We are expecting a million people; and 25 per cent have engineering, medical or technical degrees; $2-3$ per cent have at least doctoral qualifications". It is possible, Branover believes, for Israel to take a "quantum leap in high-technology fields like that seen in Japan or Korea". As for the immigrant scientists themselves, Branover says, "they are refugees. They are ready to make concessions." Government officials agree, adding that this is not the generation of 'refuseniks' who were fighting for freedom of expression and religion. In Adler's words, "now we are talking about an exodus, not an ideological aliya [immigration to Israel]".

Lisa Periman 